\title{
PENGEMBANGAN INSTRUMEN KEMAMPUAN BERPIKIR KRITIS DAN HASIL BELAJAR IPA KELAS V SD GUGUS IV KECAMATAN GEROKGAK
}

\author{
G.N. Arya Surya Wangsa ${ }^{1}$, N. Dantes ${ }^{2}$, I.W Suastra ${ }^{3}$ \\ ${ }^{123}$ Program Studi Pendidikan Dasar \\ UniversitasPendidikan Ganesha \\ Singaraja, Indonesia \\ e-mail: nguraharya868@gmail.com¹, dantes@undiksha.ac.id ${ }^{2}$, \\ iwsuastra@undiksha.ac.id ${ }^{3}$
}

\begin{abstract}
Abstrak
Penelitian ini bertujuan untuk (1) mengetahui dan mendeskripsikan validitas intrumen kemampuan berpikir kritis dan instrumen hasil belajar IPA pada mata pelajaran IPA SD. (2) mengetahui dan mendeskripsikan reliabilitas intrumen kemampuan berpikir kritis dan hasil belajar IPA SD pada mata pelajaran IPA SD. Jenis penelitian yang digunakan dalam penelitian ini merupakan penelitian pengembangan dan model pengembangan yang digunakan adalah model 4-D yang dikembangkan oleh Thiagarajan (1974). Pengembangannya terdiri dari empat tahap yaitu define, design, develop dan disseminate. Namun pada penelitian ini hanya terbatas sampai tahap develop. Dengan alasan, demi menjaga kesehatan bersama menghindari pandemi virus Covid-19 yang telah menyebar ke seluruh dunia. Hasil penelitian menunjukkan bahwa: (1) Instrumen kemampuan berpikir kritis yang dikembangkan memenuhi syarat validitas isi dengan nilai 1.00 berada pada kategori sangat baik dan sangat layak digunakan. (2) Instrumen hasil belajar IPA yang dikembangkan memenuhi syarat validitas konten dengan nilai 0,75 yang dinyatakan valid sehingga layak digunakan dalam pembelajaran. (3) Instrumen berpikir kritis yang dikembangkan memenuhi syarat reliabilitas ekpres dengan nilai 0,92 dengan kategori sangat tinggi sehingga layak digunakan dalam pembelajaran. (4) Instrumen hasil belajar IPA yang dikembangkan memenuhi syarat reliabilitas ekpres dengan nilai 0,94 dengan kategori sangat tinggi sehingga layak digunakan dalam pembelajaran.
\end{abstract}

Kata Kunci: Hasil Belajar IPA; Kemampuan Berpikir Kritis; Pengembangan Instrumen

\begin{abstract}
This study aims to (1) study and describe the validity of instruments of critical thinking skills and instruments of science learning outcomes in elementary science subjects. (2) learning and describing the reliability of the instruments of critical thinking skills and learning outcomes of elementary school natural sciences in elementary science subjects. This type of research used in this research is development research and the development model used is a 4-D model developed by Thiagarajan (1974). Its development consists of four sides, namely defining, designing, developing and disseminating. However, this research is only limited to developing. With the reason, for the sake of shared health, avoid the Covid-19 pandemic virus that has spread throughout the world. The results showed that: (1) The instrument of critical thinking skills developed content requirements with a value of 1.00 depending on the category of very good and very feasible to use. (2) The science learning outcomes instrument developed meets the content validity requirements with a value of 0.75 which is declared valid as suitable for use in learning. (3) Critical thinking instruments developed fulfill reliability requirements with a value of 0.92 with a very high category so that it is appropriate to be used in learning. (4) The science learning outcomes instrument developed meets the reliability requirements of express with a value of 0.94 with a very high category that is suitable for use in learning.
\end{abstract}

Keywords: Science Learning Outcomes; Critical Thinking Skills; Instrument Development 


\section{PENDAHULUAN}

Hasil belajar yakni kemampuan atau tingkat keberhasilan yang dimiliki oleh siswa setalah mengikuti prose belajar yang menyebabkan perubahan tingkah laku pada orang tersebut, misalnya dari tidak tau menjadi tau dan tidak bisa menjadi bisa. Perubahan perilaku yang dialami siswa mencangkup semua aspek, tidak hanya kognitif atau pengetahuannya namun, juga mencangkup aspek afektif dan psikomotorik. Hasil belajar IPA diperoleh setelah mengikuti proses belajar. Melalui proses belajar terjadi suatu perubahan tingkah laku. Perubahan tingkah laku diperoleh sesuai dengan materi IPA yang telah dipelajari baik perubahan pada ranah kognitif, afektif maupun psikomotor. Sumber belajar pada proses pembelajaran IPA tidak hanya terdapat pada buku dan guru. Namun, sumber belajat IPA bisa didapatkan melalui interaksi langsung dengan alam sekitarnya.

IPA merupakan salah satu mata pelajaran yang wajib diberikan pada siswa jenjang Sekolah Dasar.Mata pelajaran ini memegang peranan penting untuk dibelajarkan pada siswa sekolah dasar sebagai wujud mempersiapakan siswa dalam mengahadapi kehidupan sehari-hari. Samatowa (2010:3) menyatakan bahwa IPA atau Science adalah " ilmu yang mempelajari tentang alam yang mempelajari peristiwaperistiwa yang terjadi di alam ini". Pada pembelajaran IPA siswa harus terlibat aktif dalam proses pembelajaran yang diberikan oleh guru. Apabila pembelajaran IPA tidak memberikan pengalaman secara langsung kepada siswa, maka pembelajaran IPA akan sulit dipahami oleh siswa. Pada proses pembelajaran IPA, siswa tidak hanya memahami apa yang dipelajari melainkan diharapkan memperoleh sendiri jawaban dari masalah yang mereka alami sedikit demi sedikit dengan memanfaatkan alam sekitarnya.Dalam hal ini para guru diharapkan mengetahui dan mengerti tentang hakikat pembelajaran IPA dengan memperhatikan karakteristik siswa sekolah Dasar.Hakikat pembelajaran IPA dapat diklasifikasikan menjadi tiga yaitu
Ilmu pengetahuan alam sebagai produk, proses, dan sikap ilmiah. Pembelajaran IPA pada usia sekolah dasar harus benar-benar dilakukan secara mendasar dan nyata. Melalui pendidikan IPA diharapkan dapat menumbuhkan kemampuan berpikir logis, rasional, analisis, dan kristis pada siswa dalam rangka mendukung perkembangan ilmu pengetahuan dan teknologi.

Pendidikan yang bermutu salah satunya didukung oleh penerapan proses pembelajaran yang berkualitas. Dikatakan bermutu apabila, terjadinya pengkoordinasian dan penyerasian serta pemaduan input sekolah dilakukan secara harmonis dan terpadu sehingga mampu menciptakan situasi pembelajaran yang menyenangkan, mampu mendorong motivasi dan minat belajar dan mampu memberdayakan peserta didik.

Dalam proses pembelajaran, guru merupakan salah satu komponen yang berperan penting dalam menciptakan iklim belajar yang kondusif bagi siswa. Guru juga dituntut untuk terampil dalam merencanakan, melaksanakan dan mengevaluasi proses pembelajaran. Roestiyah (2008:1) menyatakan bahwa "guru harus memiliki strategi agar siswa dapat belajar secara efektif dan efisien untuk mencapai tujuan pembelajaran yang telah ditentukan". Dengan tercapainya tujuan

pembelajaran, maka dapat dikatakan bahwa guru telah berhasil dalam proses mengajar" (Djamarah, 2006:3).

Kemampuan berpikir kritis merupakan kebutuhan yang harus dimiliki oleh individu pada era belajar merdeka. Pentingnya kemampuan berpikir kritis tak lepas dari teori kontruk pemikiran dalam kurikulum 2013 menginginkan peserta didik mampu memiliki sebuah daya dalam hal membangun kerangka berpikir kritis, sehingga output yang akan dihasilkan akan benar-benar bergaransi dalam pengembangan keterampilam berpikirnya. Kemampuan ini seringkali tidak diberdayakan oleh guru dalam memahami kemampuan kognitif siswa, sehingga proses pembelajaran yang digunakan oleh guru yang hanya mengandalkan sebuah istilah yang penting pembelajaran 
berjalan, tetapi guru tidak memahami bahwa bukan hanya dari kemampuan kognitif siswa akan tercapai. Kemampuan seseorang untuk dapat berhasil dalam kehidupannya ditentukan oleh keterampilan berpikir sebagai upaya dalam memecahkan masalah-masalah kehidupan yang dihadapi. Kemampuan berpikir kritis akan mempengaruhi keberhasilan hidup karena terkait apa yang akan dikerjakan dan apa yang abkan menjadi output individu. Mengingat pentingnya kemampuan berpikir kritis banyak upaya yang dilakukan oleh pemerintah yaitu mengintegrasikan kemampuan berpikir kritis ke dalam kurikulum pendidikan. Pembelajaran IPA akan sangat bermakna ketika proses pembelajaran dapat dimengerti dan dipahami oleh siswa. Menumbuhkan rasa ingin tahu siswa yang beda dan mengajarkan mereka untuk berpikir kritis menghadapi masalah-masalah yang ada di dalam pelajaran IPA. Permasalahan yang mampu meransang kemapuan siswa dalam berpikir kritis karena dengan menyelesaikan permasalah padamuatan IPA siswa mampu berpikir secara kritis, logis dan ilmiah sehingga kemampuan mereka dalam berpikir kritis juga dapat terus dikembangkan. Namun pada kenyataannya kemampuan berpikir kritis siswa pada pembelajaran IPA belum sesui dengan yang diharapkan, meskipun pemerintah telah melalukan berbagai upaya untuk menterjadikan dan mengoptimalkan pembelajaran IPA sesuai tujuan. Ini dapat dilihat dari survei PISA Indonesia menempati peringkat ke 62 dengan nilai rata-rata kemampuan IPA yaitu 403. Dengan demikian menunjukkan bhawa kemampuan problem solving IPA pada peserta didik rendah. (Maulidati, 2018). Hal tersebut menunjukkan bahwa kemampuan berpikir kritis siswa berada pada kategori rendah. Tinggi rendahnya kemampuan berpikir kritis akan berdampak pada hasil belajar siswa.

Hasil penilaian PISA menjadi gambar pendidikan di Indonesia yang berharga untuk mengevaluasi dan meningkatkan kualitas pendidikan di Indonesia yang akan menjadi fokus Pemerintah untuk menekankan pentingnya kompetensi guna meningkatkan kualitas dan mutu pendidikan untuk menghadapi tantangan abad 21. Demi mencapai tujuan tersebut, Kemendikbud akan melakukan inovasi dan terobosan yang diperlukan untuk mempercepat proses dan melakukan lompatan di bidang pendidikan. Kurikulum 2013 yang mengharapkan siswa untuk memunculkan kemampuan berpikir kritis dalam evaluasi pembelajaran, maka assemen tes tertulis yang dapat dibuat guru diharapkan mampu mengarahkan siswa untuk memunculkan kemampuan berpikir kritis dalam membuat pemecahan masalah pada asesmen tersebut. Adapun permasalahan yang terjadi di lapangan instrument asesmen yang dirancang guru untuk ranah kognitif masih berfokus pada tingkatan pengetahuan (C1) dan pemahaman (C2), selain itu pengetahuan guru tentang asesmen masih sangat rendah dan belum bisa membuat instrument asesmen yang standar. Selain itu asesmen saat ini lebih ditekankan pada pemikiran reproduktif, hafalan dan mencari satu jawaban benar terhadap soal-soal yang diberikan. Proses berpikir tingkat tinggi termasuk berpikir kritis jarang dilatihkan. Pembelajaran IPA masih menitikberatkan pada pemahaman konsep siswa saja, siswa jarang dilatih untuk memecahkan masalah.

Berdasarkan permasalahan tersebut, maka perlu disusun suatu instrumen tes tertulis yang mampu mengukur kemampuan berpikir kritis siswa dan ketercapaian siswa terhadap indikator pembelajaran. Oleh karena itu, maka perlu dilakukan penelitian mengenai pengembangan instrumen kemampuan berpikir kritis dan hasil belajara IPA kelas V Gugus IV Kecamatan Gerokgak.

\section{METODE}

Penelitian ini merupakan penelitian dan pengembangan yang bertujuan untuk mengembangkan instrumen kemampuan berpikir kritis dan hasil belajar IPA kelas $\mathrm{V}$ SD. Penelitian ini menggunakan model penelitian dan pengembangan pendidikan (educational research and development). Pengembangan produk pendidikan dalam penelitian ini adalah berupa pengembangan instrumen kemampuan 
berpikir kritis dan hasil belajar IPA kelas $\mathrm{V}$ SD. Model pengembangan yang digunakan dalam penelitian ini adalah difine (pendefinisian), design (perencanaan), development (pengembangan) yang disebut dengan 4D (define, design, development, dan dessemination) (Thiagarajan et al, 1974 dalam Trianto, 2012).

Subyek penelitian ini adalah pakar ahli dan praktisi. Terdiri dua orang pakar ahli yaitu dosen pendas dan tiga pakar praktisi yaitu guru kelas V SD yang mevalidasi dan mengobservasi pelaksanaan pengembangan, serta mampu memberikan saran, masukan, dan komentar untuk dijadikan bahan revisi terhadap instrumen yang dikembangkan.

\section{Analisis Data}

Validitas penelitian adalah kemampuan suatu penelitian untuk mengungkapkan secara tepat mengenai apa yang ingin diteliti (Dantes 2012:86). Dalam penelitian ini validitas yang diuji yaituinstrumen kemampuan berpikir kritis dan hasil belajar IPA diuji terlebih validasi oleh 3 pratisi dari guru SD dan 2 dosen Pendas. Instrumen disebut valid apabila benar-benar mampu mengukur apa yang semestinya diukur dengan instrumen tersebut (Candiasa, 2010:21).

Hasil validasi dari validator dianalisis menggunakan analisis Isi Validity Ratio (CVR) dengan rumus berikut:$$
\mathrm{CVR}=(2 n e / n)-1
$$

(Azwar, $2013: 114)$

Setelah mengidentifikasi setiap sub pertanyaan instrumen dengan menggunakan CVR, maka selanjutnya yaitu menghitung CVI (Isi Validity Index). CVI digunakan untuk menghitung ratarata dari keseluruhan nilai CVR untuk komponen instrumen kemampuan berpikir kritis dan hasil belajar IPA. Adapun rumus $\mathrm{CVI}$, yaitu sebagai berikut:

$$
\mathrm{CVI}=\left(\sum \mathrm{CVR}\right) / \mathrm{k}
$$

(Azwar, 2013:115)

Setelah dilakukan uji validitas, uji selanjutnya ialah melakukan pengujian terhadap reliabilitas instrument.Reliabilitas yang dihitung hanya untuk butir-butir yang tidak gugur (valid). Dengan kata lain, butir-butir yang tidak valid tidak diikutsertakan dalam pengujian atau perhitungan reliabilitas (Koyan, 2011: 135). Dalam penelitian ini, untuk menentukan reliabilitas kemampuan berpikir kritis yang sifatnya politomi digunakan Alpha Cronbach dengan rumus sebagai berikut.

$$
\mathrm{r}_{1.1}=\left(\frac{k}{k-1}\right)\left(\frac{S D^{2}{ }_{t o t}-\sum S D_{i}^{2}}{S D_{t o t}{ }^{2}}\right)
$$

$$
\text { (Koyan, 2011: 135) }
$$

Selanjutnya hasilperhitungan atau pengujian reliabilitas yang telah diperoleh dibandingkan dengan kriteria reliabiltas. Berdasarkan cara perhitungan reliabilitas yang sama, maka untuk analisis koefisien korelasi pada butir-butir kemampuan berpikir kritis selanjutnya dianalisis dengan komputer. Perhitungan menggunakan bantuan komputer paket program Microsoft Office Excel 2007. Langkah ini dilakukan untuk medapatkan hasil perhitungan dalam kurun waktu yang singkat.

Uji reliabilitas yang dapat digunakan untuk menguji butir soal hasil belajar adalah formula atau rumus KR-20. K-R singkatan dari Kuder dan Richardson, sedangkan 20 merupakan catatan bilangan yang menemukan banyak replikasi perhitungan sampai penemuan rumus tersebut. Skor hasil belajar ini merupakan skor dikotomi yang dihitung dengan menggunakan rumus sebagai berikut:

$r_{1.1}=\left(\frac{n}{n-1}\right)\left(\frac{S_{t}^{2} \sum p q}{S_{t}^{2}}\right)$

$$
\text { (Candiasa, 2010:53) }
$$

\section{HASIL DAN PEMBAHASAN Validitas dan Reliabilitas Instrumen Kemampuan Berpikir Kritis}

Intrumen yang digunakan dalam penelitian ini meliputi lembar validasi intrumen kemampuan berpikir kritis. Setelah produk awal dapat dijalankan dengan lancar, dilanjutkan pada tahap validasi, yaitu validasi oleh ahli dan praktisi dilanjutkan revisi produk tahap pertama, kemudian dilakukan uji validitas kontendilanjutkan revisi produk akhir. Deskripsi data hasil uji ahli dan praktisi dipaparkan pada tabel berikut. 
Tabel Kerja untuk Menghitung Validitas content bila penilaianya lebih dari 1 maka dihitung menggunakan rumus Lawshe $C V R=\frac{n_{e}-\frac{N}{2}}{\frac{N}{2}}=\frac{2 n e}{n} 1$

Tabel 1. Perhiungan Validitas Isi Kemampuan Berpikir Kritis

\begin{tabular}{|c|c|c|c|c|}
\hline No Butir & Relevan & Tidak Relevan & CVR & Status \\
\hline 1 & 5 & 0 & 1 & Valid \\
\hline 2 & 5 & 0 & 1 & Valid \\
\hline 3 & 5 & 0 & 1 & Valid \\
\hline 4 & 5 & 0 & 1 & Valid \\
\hline 5 & 5 & 0 & 1 & Valid \\
\hline 6 & 5 & 0 & 1 & Valid \\
\hline 7 & 5 & 0 & 1 & Valid \\
\hline 8 & 5 & 0 & 1 & Valid \\
\hline 9 & 5 & 0 & 1 & Valid \\
\hline 10 & 5 & 0 & 1 & Valid \\
\hline & $\Sigma$ CVR & \multicolumn{3}{|c|}{10} \\
\hline
\end{tabular}

2) Menghitung Isi Validity Index (CVI)

$$
C V I=\frac{\sum \mathrm{CVR}}{k} \quad C V I=\frac{10}{10}=1
$$

Berdasarkan hasil validasi ahli dan praktisi dengan rincian 2 validasi ahli dari pakar (dosen) yang membidangi pengembangan instrumen kemampuan berpikir kritis dan 3 orang guru kelas $\mathrm{V}$ SD maka diperoleh hasil perhitungan dengan rumus Lawshe. Berdasarkan hasil perhitungan tersebut diperoleh hasil 1,00 dikategorikan ke klasifikasi valid tanpa perlu direvisi lagi.

Selanjutnya dilakukan Uji reliabilitas instrumen kemampuan berpikir kritis pada pembelajaran IPA kelas V SD diuji oleh 5 pakar yaitu 2 ahli dan 3 praktisi (guru). Nilai-nilai untuk pengujian reliabilitas diambil dari skor-skor item kemampuan berpikir kritis yang dinyatakan valid atau terpakai. Item yang tidak valid tidak dilibatkan dalam pengujian reliabilitas. Dalam hal ini semua butir insturmen kemampuan berpikir kritis dinyatakan valid, maka dari itu semua instrumen kemampuan berpikir kritis dapat di uji reliabilitasnya.
Uji reliabilitas instrumen kemampuan berpikir kritis diuji dengan menggunakan teknik formula Alpha Cronbach. Menurut Arikunto (2009), rumus Alpha Cronbach digunakan untuk mencari reliabillitas instrumen yang skornya bukan 1 dan 0 , seperti angket atau soal bentuk uraian. Table kerja untuk menghitung reliabilitas instrumenkemampuan berpikir kritis dengan 5 pakar menggunakan rumus Alpha Cronbach Berdasarkan hasil perhitungan diperoleh nilai kemampuan berpikir kritis yang valid, kofisien reliabilitas sebesar 0,92 berada pada kategori sangat tinggi.

\section{Validitas dan Reliabilitas Instrumen Hasil Belajar IPA}

Instrumen yang dikembangkan dalam penelitian ini adalah instrumen hasil IPA kelas V SD. Instrumen hasil belajar IPA tersebut diuji validasi oleh 5 pakar yaitu 2 ahli dan 3 praktisi (guru). Deskripsi kriteria penggolongan validitas uji judges instrumen hasil belajar IPA dengan 5 pakar dipaparkan pada tabel 02 . sebagai berikut.

Tabel 2. Perhiungan Validitas Isi Hasil Belajar IPA

\begin{tabular}{ccccc}
\hline No Butir & Relevan & $\begin{array}{c}\text { Tidak } \\
\text { Relevan }\end{array}$ & CVR & Status \\
\hline 1 & 5 & 0 & 1 & Valid \\
2 & 4 & 1 & 0.6 & Valid \\
3 & 3 & 2 & 0.2 & Valid \\
4 & 4 & 1 & 0.6 & Valid \\
\hline
\end{tabular}




\begin{tabular}{ccccc}
\hline No Butir & Relevan & $\begin{array}{c}\text { Tidak } \\
\text { Relevan }\end{array}$ & CVR & Status \\
\hline 5 & 4 & 1 & 0.6 & Valid \\
6 & 5 & 0 & 1 & Valid \\
7 & 5 & 0 & 1 & Valid \\
8 & 4 & 1 & 0.6 & Valid \\
9 & 4 & 1 & 0.6 & Valid \\
10 & 5 & 0 & 1 & Valid \\
11 & 5 & 0 & 1 & Valid \\
12 & 4 & 1 & 0.6 & Valid \\
13 & 5 & 0 & 1 & Valid \\
14 & 5 & 0 & 1 & Valid \\
15 & 5 & 0 & 1 & Valid \\
16 & 4 & 1 & 0.6 & Valid \\
17 & 5 & 0 & 1 & Valid \\
18 & 3 & 2 & 0.2 & Valid \\
19 & 5 & 0 & 1 & Valid \\
20 & 5 & 0 & 1 & Valid \\
21 & 4 & 1 & 0.6 & Valid \\
22 & 5 & 0 & 1 & Valid \\
23 & 3 & 2 & 0.4 & Valid \\
24 & 5 & 0 & 1 & Valid \\
25 & 5 & 0 & 1 & Valid \\
26 & 4 & 1 & 0.6 & Valid \\
27 & 4 & 1 & 0.6 & Valid \\
28 & 4 & 1 & 0.6 & Valid \\
29 & 4 & 1 & 0.6 & Valid \\
30 & 4 & 1 & 0.6 & Valid \\
& 5 CVR & & 22.6 & \\
\hline
\end{tabular}

Berdasarkan hasil uji validitas content pengembangan produk instrumen hasil belajar IPA dengan 5 pakar yakni 2 dosen ahli dan 3 praktisi (guru) menggunakan rumus lawshe mendapatkan hasil bahwa semua butir instrumenhasil belajar IPA dikategorikan valid dan layak digunakan tanpa perlu direvisi kembali. Kemudian melakukan perhitungan isi validity index instrumen hasil belajar IPA yang di kembangkan mendapatkan hasil sebesar $\mathrm{CVI}=0,75$. Hal ini berarti, instrumenhasil belajar IPA yang di kembangkan termasuk ke dalam kriteria valid.

Setelah uji validitas selanjutnya dilakukan uji reliabilitas. Berdasarkan data di atas, dapat dihitung reliabilitas instrumen hasil belajar IPA sebagai berikut.

$$
\begin{aligned}
& r_{1.1}=\left(\frac{n}{n-1}\right)\left(\frac{S_{t}^{2} \sum p q}{S_{t}^{2}}\right) \\
& r_{1.1}=\left(\frac{30}{30-1}\right)\left(\frac{30.20-0.00}{30.20}\right)
\end{aligned}
$$

$=0.94$

Jadi, dengan menggunakan formula KR-20. Reliabilitas instrumen hasil belajar IPA adalah 0.94. Dengan demikian, dapat disimpulkan bahwa ke 30 butir soal tersebut telah memiliki reliabilitas yang sangat tinggi.

\section{PEMBAHASAN}

Hasil-hasil penelitian yang telah dilakukan akan dipaparkan pada pembahasan. Adapun hasil penelitian yang dibahas meliputi validitas intrumen kemampuan berpikir kritis dan hasil belajar IPA kelas V SD dan Reliabilitas instrumen kemampuan berpikir kritis dan hasil belajar IPA.

\section{Validasi Intrumen Kemampuan Berpiki Kritis}

Validasi intrumen kemampuan berpikir kritis ditempuh melalui dua tahapan validasi yaitu validasi ahli dan praktisi Validasi dilakukan oleh 2 orang pakar yang berasal dari kalangan dosen 
yang berkopenten di bidangnya dan 3 orang praktisi yang berasal dari guru kelas V SD. Hasil perhitungan validasi ahli dan praktisi hasil yang didapat pada pengembangan produk intumen kemampuan berpikir kritis capaiannya 1.00. Berdasarkan perhitungan tersebut, maka instrumen kemampuan berpikir kritis telah memenuhi validasi atau valid, hal ini sejalan dengan penelitian yang dilakukan oleh Mukti \& Istiyono (2018), hasil penelitian menunjukkan bahwa (a)Intstrumen tes memenuhi syarat validitas isi expert judgment dan memperoleh bukti empiris kecocokan model (goodness of fit tes) pada model PCM (Partial Credit Model) berdasarkan skor politomus empat kategori, (b) Instrument tes mempunyai tingkat kesulitan yang baik dengan rentang nilai 2,00 dan 2,00.(c) Instrumen tes mempunyai nilai reliabilitas yang tinggi yaitu sebesar 0,86 sehingga instrumen tes berpikir kritis memenuhi syarat sebagai alat ukur yang baik. (d) Instrumen tes dapat digunakan untuk mengukur kemampuan berpikir kritis dengan rentang kemampuan sebesar $-3,7$ sampai dengan 2,90.

Selanjutnya penelitian yang dilakukan oleh Trimawati \& Raharjo (2020), hasil penelitian menunjukkan bahwa (a) perangkat pembelajaran dan instrumen penilaian IPA Terpadu yang dikembangkan berkategori sangat valid dengan nilai modus 5, (b) kegiatan pembelajaran terlaksana sangat baik dengan nilai modus 5, (c) aktivitas siswa dalam pembelajaran terlaksana sangat baik dengan nilai modus 5 , (d) respon siswa terhadap pembelajaran proyek cukup baik dengan kisaran angka antara $50 \%-60 \%$, dan (e) hasil tes berpikir kritis dan kreatif siswa ada peningkatan yang baik pula, kemampuan berpikir kritis meningkat dari 25,85 (Kurang Kritis) menjadi 87,76 (Sangat Kritis) dan kemampuan berpikir kreatif meningkat dari 20,44 (Kurang Kreatif) menjadi 84,85 (Sangat Kreatif). Simpulan pengembangan perangkat pembelajaran dan instrumen penilaian IPA Terpadu dalam pembelajaran Project Based Learning yang dikembangkan layak digunakan untuk meningkatkan kemampuan berpikir kritis dan kreatif siswa.

Diperolehnya

intrumen

kemampuan berpikir kritis di kelas $\mathrm{V}$ yang sangat baik dan sangat layak digunakan disebabkan oleh beberapa faktor. Produk instrumen kemampuan berpikir kritis sesuai dengan aspek-aspek pengukuran validatas yaitu validitas isi. Produk intsrumen memenuhi validitas isi berarti dalam pengembangannya telah didasarkan atas isi dari teori-teori yang dijadikan acuan dalam perumusan ataupun penyusunan. Sedangkan produk instumen yang memenuhi validitas konstruk berarti dalam pengembangannya memperhatikan keterkaitan antara materi, kurikulum 2013 dan aspek-aspek kemampuan berpikir kritis. Hal tersebut dapat mengarahkan siswa untuk mampu memahami materi atau konsep yang dipelajari, dan meningkatkan kemampuan berpikir. Selain itu intrumen berfungsi untuk memahami dan mengarahkan potensi dari seorang peserta didik agar dapat menggali terus potensinya dan memperbaiki kelemahannya.Sedangkan untuk peserta didik, kurikulum berfungsi untuk membantu mereka agar dapat memahami materi dan melaksanakan proses pembelajaran dengan mudah, sehingga target pembelajaran dapat tercapai. Tujuan utama kurikulum adalah untuk mempersiapkan peserta didik agar dapat menjadi pribadi serta warga negara yang kreatif, inovatif, beriman, dan juga afektif ketika dia berada pada lingkungan masyarakat kelak.Selain itu, peserta didik juga diharapkan mendapatkan pengalaman baru yang bisa saja menjadi bekal di kehidupannya nanti.

Faktor-faktor tersebut diatas menyebabkan produk instrument kemampuan berpikir kritis yang dikembangkan telah memenuhi kriteria sangat baik sesuai dengan yang diharapkan, baik dari segi isi dan konstruk sehingga sangat layak untuk digunakan dalam pembelajaran.

\section{Reliabilitas Intrumen Kemampuan Berpikir Kritis}

Reliabiltas instrumen mengacu pada konsistensi hasil pengukuran yang 
ditunjukkan oleh instrumen tersebut. Instrumen yang memiliki reliabiltas yang tinggi akan memberikan hasil yang relatif sama, sekalipun instrumen tersebut digunakan dalam kurun waktu yang berbeda. Reliabilitas instrumen kemampuan berpikir kritis dilakukan dengan formula Alpha Cronbach karena pada dasarnya formula Alpha Cronbach lebih umum diterapkan untuk menghitung reliabilitas tes politomi. Sejalan dengan Arikunto (2009), rumus Alpha Cronbach digunakan untuk mencari reliabillitas instrumen yang skornya bukan 1 dan 0 , seperti angket atau soal bentuk uraian. Berdasarkan reliabilitas intrumen kemampuan berpikir kritis setelah dihitung memperoleh hasil 0.92 dengan kategori sangat tinggi. Dwipayani (dalam Khoiriah 2018) juga menjelaskan tentang soal perangkat yang dinyatakan berkualitas baik jika memiliki indeks validitas dan reliabilitas yang tinggi.

\section{Validasi Intrumen Hasil Belajar IPA Kelas V SD}

Setelah dilakukan analisis terhadap validitas intrumen hasil belajar IPA kelas V SD. Hasil menunjukkan bahwa intrumen hasi Ibelajar IPA valid untuk digunakan dalam evaluasi pembelajaran untuk mengetahui kemampuan yang dimiliki siswa. Sejalan dengan teori Benyamin Bloom dalam Wardani, N. S., dkk (2012:193) menyatakan bahwa, ranah kognitif adalah kemampuan intelektual siswa dalam berpikir mengetahui dan memecahkan masalah. Dengan kata lain, beliau mengungkapkan bahwa proses kognitif yang menunjukkan keterampilan berpikir sesuai revisi taksonomi bloom diformulasikan menjadi 6 kategori yaitu, mengingat, memahami, menerapkan, mengevalusi, dan menciptakan. Penilaian pengetahuan atau kognitif berdasarkan permendikbud nomor 23 tahun 2016 tentang standar penilaian pendidikan merupakan kegaiatan yang dilakukan untuk mengukur penguasaan pengetahuan peserta didik. Jadi, dapat disimpulkan bahwa pengembangan intrumen hasil belajar IPA berfungsi untuk mengukur aspek kognitif sesuai dengan kemampuan berpikir yang telah dicetuskan oleh taksonomi bloom.

Validasi intrumen hasil belajar IPA kelas V SD ditempuh melalui dua tahapan validasi yaitu validasi ahli dan praktisi Validasi dilakukan oleh 2 orang pakar yang berasal dari kalangan dosen yang berkopenten di bidangnya dan 3 orang praktisi yang berasal dari guru kelas $V$ SD. Rata-rata skor validitas berdasarkan hasil validasi ahli dan praktisi hasil yang didapat pada pengembangan produk intumen hasil belajar IPA kelas V SD capaiannya 0,75 . Secara keseluruhan intumen hasil belajar IPA kelas V SD dikategorikan sangat baik dan sangat layak digunakan dengan tidak perlu direvisi.

Hasil penelitian tersebut sejalan dengan (Utami \& Wardani, 2020), (1) cara mengembangkan intrumen penilaian kognitif yaitu menentukan tema, $\mathrm{KI}, \mathrm{KD}$, IPK, tujuan pembelajaran, alat ukur, kisikisi, butir soal, uji coba, revisi dan menentukan produk akhir, (2) intrumen butir soal berbentuk PG terdiri dari 42 butir. Berdasarkan analisis secara klasik, butir soal memiliki validitas tinggi $r \geq 0,20$, reliabilitas $\alpha \geq 0,20 \quad(\alpha=938)$, tingkat kesukaran sedang, daya pembeda diterima, daya pengecoh sangat baik, dan baik. Dengan demikian, intrumen penilaian kognitif pembelajaran tematik kelas V SD layak digunakan. Adanya intrumen penilaian kognitif berupa butir soal yang baik sangat diperlukan agar dapat mengukur kemampuan peserta didik dengan tepat sesuai tujuan pembelajaran yang diharapkan. Penilaian jika diterapkan dengan benar dapat meningkatkan kualitas pembelajaran. Lebih lanjut relevan dengan pernyataan berikut,

How making your own assessments improve your teaching: (1) knowing how to choose or to craft quality assessments increases the qua-lity of your teaching decisions; (2) what and how you assess communicated in a powerful way what you really value in your students learning; (3) when you carefully define assessment tasks, you are clarifying what you want students to learn; (4) you use your knowledge of how to craft quality assessment tasks when you evaluate 
assessment materials available from other source; (5) learning to craft assessment tasks increases your freedom to design lesson; 6) you will improve the validity of your interpretations and uses of assessment result. (Nitko. \& Brookhart, 2007, p. 107) dalam Suryani (2017).

Merujuk pendapat di atas dapat ditarik simpulan bahwa, penilaian tidak hanya berpengaruh terhadap keberhasilan siswa tetapi penilaian dapat meningkatkan kualitas guru dalam mengajar. Penilaian juga menjelaskan apa yang dibutuhkan peserta didik, hasil dari penilaian dapat meningkatkan validitas interpretasi guru terhadap siswa sehingga penilaian berpengaruh terhadap peningkatan kualitas pembelajaran. Instrumen yang baik dan layak digunakan harus sudah divalidasi. Suryani (2017) Tujuan dari validasi adalah untuk mendapatkan umpan balik, kritik saran tentang peningkatan model sesuai dengan bidang keahlian masing-masing pelaku validasi. Validitas ahli bertujuan untuk memberikan penilaian terhadap item dalam instrumen. Penilaian berkaitan dengan kemampuan poin terhadap indikator.

\section{Reliabilitas Intrumen Hasil Belajar IPA}

Uji Reliabilitas yang dapat digunakan untuk menguji butir soal hasil belajar IPA adalah formula atau rumus KR-20. K-R singkatan dari Kuder dan Richardson, sedangkan 20 merupakan catatan bilangan yang menemukan banyak replikasi perhitungan sampai penemuan rumus tersebut. Skor hasil belajar IPA merupakan skor dikotomi. Berdasarkan hasil perhitungan uji reliabilitas hasil belajar IPA diperoleh hasil 0,94 berada pada kategori sangat tinggi. Artinya sesuai hasil yang diperoleh instrumen hasil belajar IPA layak digunakan di Sekolah Dasar.

\section{PENUTUP}

Penelitian ini dilakukan berangkat dari adanya permasalahan dalam instrumen yang digunakan pada jenjang anak Sekolah Dasar. Permasalahan yang dimaksud adalah (1) pencapaian tujuan pembelajaran untuk mata pelajaran IPA SD masih tergolong relatif rendah dibandingkan dengan mata pelajaran lainnya hal ini dikarenakan kurangnya penyerapan materi dalam mengikuti pembelajaran, (2) kurang adanya memunculkan keterampilan berpikir kritis dalam mengembangkan potensi siswa ada pelajaran IPA, (3) instrumen asesmen yang dibuat oleh guru masih terbatas pada tingkat pengetahuan (C1) dan pemahaman (C2), belum mengukur keterampilan berpikir tingkat tinggi, (4) instrumen ssesmen kemampuan berpikir kritis siswa belum pernah dikembangkan oleh guru. Untuk itu guru perlu mengembangkan intrumen untuk mengukur keberhasilan siswa mencapai tujuan pembelajaran yang bermakna salah satu instrumen yang dapat meningkatkan kemampuan berpikir tingkat tinggi yaitu kemampuan berpikir kritis. Pada tahap ini ada beberapa langkah yang dilakukan sebagai berikut.

a) Analisis awal-akhir, dilakukan untuk menetapkan masalah yang dihadapi dan perlu diangkat dalam pengembangan intrumen pembelajaran. Peneliti menemukan permasalahan bahwa : (a) instrument asesmen yang dirancang guru untuk ranah kognitif masih berfokus pada tingkatan pengetahuan (C1) dan pemahaman (C2), selain itu pengetahuan guru tentang asesmen masih sangat rendah dan belum bisa membuat instrument asesmen yang standar tidak berbasis problem solving. Selain itu asesmen saat ini lebih ditekankan pada pemikiran reproduktif, hafalan dan mencari satu jawaban benar terhadap soal-soal yang diberikan. Proses berpikir tingkat tinggi termasuk berpikir kritis jarang dilatihkan, yang menyebabkan siswa belum mampu mengkontruksikan konsep yang dipelajarinya dengan pemecahan masalah dikehidupan nyata, selain itu siswa cenderung menghapalkan tanpa memahami secara mendalam konsep yang dipelajarinya. Berdasarkan pemikiran ini, maka peneliti mengembangkan intrumen kemampuan berpikir kritis dan hasil belajar IPA untuk kelas $\vee \mathrm{SD}$.

b) Analisis peserta didik, menunjukkan bahwa pembelajaran yang dilakukan belum membelajarkan siswa, dimana guru menjelaskan materi pembelajaran 
siswa mendengarkan kemudia siswa mengerjakan tugas LKS yang kegiatannya hanya mengisi bagianbagian yang kosong dengan istilah-istilah dari konsep pembelajaran, tanpa ada proses pengamatan, pada evaluasi pembelajaran guru jarang memberikan soal-soal yang melatih pengetahuan dengan meningkatkan kemampuan berpikir kritis siswa, siswa jarang dihadapkan pada dunia yang ada disekitarnya dalam proses pembelajaran, padahal pada anak usia SD berada pada tahap operasional konret. Alasan yang diungkapkan guru, tidak adanya alat dan bahan di sekolah, dan juga intrumen untuk siswa sudah disiapkan oleh pemerintah tinggal diberikan kepada siswa.

c) Analisis materi, dilakukan dengan mengkaji struktur kurikulum 2013 untuk muatan pelajaran IPA untuk kelas $\mathrm{V} S \mathrm{SD}$. Pendekatan saintifik yang disyaratkan dalam implementasi kurikulum 2013 sebagaimana terdapat pada Permendikbud No 81 A tahun 2013 menuntut guru untuk jeli menentukan strategi pembelajaran sehingga tujuan pembelajaran apat dicapai. Supaya kemampuan berpikir kritis siswa dapat terbentuk dengan baik maka diperlukan pelajaran IPA yang tidak hanya belajar konsep atau prinsip-prinsip IPA tetapi juga siswa dapat memecahkan masalah yang timbul dalam kehidupan seharaihari. Hasil diskusi dengan guru Gugus III Gerokgak, materi yang dipilih adalah terkait dengan penghematan energi, dan siklus air. Materi ini dipilih karena terdapat banyak masalah nyata yang timbul dalam kehidupan siswa sehari-hari yang ada kaitnnya dengan materi tersebut.

Hasil penelitian ini berupa suatu produk instrument kemampuan berpikir kritis dan hasil belajar IPA untuk kelas $\mathrm{V}$ SD. Intrumen kemampuan berpikir kritis dan hasil belajar IPA, produk ini sudah merupakan instrument yang valid. Namun sebelum menghasilkan produk intrumen valid akan melalui beberapa tahap pengembangan yang mengacu pada model pengembangan 4D yang dikemukakan oleh Thiagarajan yang meliputi: (1) Define, (2) Design, (3) Development, dan (4) Desseminate.
Tetapi penelitian ini hanya sampai pada tahap development dengan alasan untuk menjaga kesehatan bersama akibat pandemi virus Covid-19 yang telah menyebar ke seluruh Dunia.

Berdasarkan hasil pengembangan diperoleh instrumen kemampuan berpikir kritis dan hasil belajar IPA yang telah memenuhi kualitas yang baik, baik dari segi aspek validitas, reliabilitas. Hasil uji validitas menunjukkan bahwa instrumen yang dikembangkan berada pada kategori valid.

Berdasarkan laporan hasil penelitian seperti yang telah dipaparkan pada bagian sebelumnya, maka dapat disimpulkan beberapa hasil penelitian sebagai berikut.

1. Instrumen kemampuan berpikir kritis yang dikembangkan memenuhi syarat validitas konten dengan nilai 1.00dengan kategori sangat baik dan sangat layak digunakan.

2. Instrumen berpikir kritis yang dikembangkan memenuhi syarat reliabilitas expert dengan nilai 0,92 dengan kategori sangat tinggi sehingga layak digunakan dalam pembelajaran.

2. Instrumen hasil belajar IPA yang dikembangkan memenuhi syarat validitas konten dengan nilai 0,75 yang dinyatakan valid sehingga layak digunakan dalam pembelajaran.

4. Instrumen hasil belajar IPA yang dikembangkan memenuhi syarat reliabilitas expert dengan nilai 0,94 dengan kategori sangat tinggi sehingga layak digunakan dalam pembelajaran.

Mengacu pada rumusan masalah dan didukung oleh laporan hasil penelitian dalam penelitian ini, dapat diajukan saran sebagai berikut.

Adapun saran yang disampaikan dalam penelitian pengembangan instrumen kemampuan berpikir kritis dan hasil belajar IPA sebagai berikut.

Bagi guru, hendaknya benarbenar paham bagaimana langkahlangkah dalam menysun instrumen yang berkualitas dengan memperhatikan KD, indikator mengacu ke Lower and Higher Order Thinking Skills (L\&HOTS), yakni skala C1, C2, C3, dan C4 pada 
taksonomi Bloom. Di samping itu, persyaratan instrument dari sisi (a) substansi, yakni merepresentasikan kompetensi yang dinilai; (b) konstruksi, yakni memenuhi persyaratan teknis sesuai dengan bentuk instrumen yang digunakan; dan (c) bahasa, yakni menggunakan bahasa yang baik dan benar serta komunikatif sesuai dengan taraf perkembangan peserta didik dapat dipahami dengan baik oleh peserta. Bagi Kepala Sekolah, sebaiknya memberikan stimulus kepada guru-guru dengan melaksanakan kegiatan diklat, bimtek, workshop dan lain-lain guna memberikan pelatihan yang dapat menambah wawasan guru terkait dengan penyusunan instrumen dengan semaksimal mungkin. Selain hal tersebut, Kepada Sekolah perlu melakukan penilaian terhadap kinerja guru, serta memberikan bimbingan secara khusus. Bagi Peneliti lain, Kepada peneliti lain disarankan agar hasil penelitian ini dapat digunakan sebagai acuan kepustakaan untuk melakukan penelitian dalam variabel yang sama dan memperhatikan kendala-kendala yang dialami dalam penelitian ini sebagai bahan pertimbangan untuk perbaikan dan penyempurnaan yang akan dilaksanakan. Pengembangan dari keterbatasan penelitian ini, karena penelitian yang dilakukan baru sampai pada tahapan development (pengembangan). Tahapan lebih lanjut dapat dilakukan sampai disseminate (penyebaran) produk.

\section{DAFTAR RUJUKAN}

Arikunto, Suharsimi. 2009. Dasar-dasar evaluasi pendidikan. Jakarta: PT Bumi Aksara.

Azwar, Saifuddin. 2013. Reliabilitas dan Validitas. Yogyakarta: Pustaka Pelajar.

Candiasa, I.M. 2010.Pengujian Instrumen Penelitian Disertai Aplikasi ITEMAN DAN BIGSTEP. Singaraja: Unit Penerbitan Universitas Pendidikan Ganesha.
Dantes, N. 2012.Metodologi Penelitian. Yogyakarta: Andi. ISBN: 978-97929-3463-2.

Djamarah, S. B dan Zain, A. 2006. Stategi Belajar Mengajar. Jakarta: Rimeka Cipta.

Maulidati.S. $2018 . \quad$ "Pengaruh Pembelajaran Berbendekatan Saintifik Berorientasi Science Environment Technology Society Terhadap Kemampuan Berpikir Kritis dan Hasil Belajar IPA Siswa Kelas V". Jurnal Pendidikan Dasar Indonesia. Volume 2 Nomor 2.

Roestiyah. 2008. Strategi Belajar Mengajar. Jakarta: PT Rineka Cipta.

Samatowa, Usman. 2011. Pembelajaran IPA di Sekolah Dasar. Jakarta: PT Indeks.

Sumayasa, I Nyoman.2015. Pengaruh Implementasi Pendekatan Saintifik Terhadap Motivasi Belajar dan Hasi Belajar IPA Pada Siswa Kelas VI di Sekolah Dasar Gugus VI Kecamatan Abang Karangasem.E-jurnal Program pascasarjana Universitas Pendidikan Ganesha.Volume 5.

Suryani, Helmiah. 2017. " Development and Validity of Mathematical Learning Assessment Instruments Based on Multiple Intelligence". Jurnal Penelitian dan Evaluasi Pendidikan. Volume 21 No 1.

Trimawati, Karina, dkk. 2020. "Pengembangan Intrumen Penilaian IPA Terpadu dalam Pembelajaran Model Project Based Learning (PjBL) untuk Meningkatkan Kemampuan Berpikir Kritis dan Kreatif Siswa SMP". Quantum: Jurnal Inovasi Pendidikan Sains, Vol. 11, No. 1, 2020, 36-52.

Utami, Diah Ayu Putri, Wardani, Naniek Sulistya. 2020. "Pengembangan Intrumen Penialain Kognitif dalam Pembelajaran Tematik Kelas 5 SD". Lentera: Jurnal IImiah Kependidikan, Vol. 13, No. 1 (2020), 1-18.

Wardani, Naniek Sulistya, dkk. 2012. Assesmen Pembelajaran SD. 
Vol.5 No 1, Pebruari 2021

ISSN: 2613-9553

Kabupaten Semarang: Widya Sari

Press. 